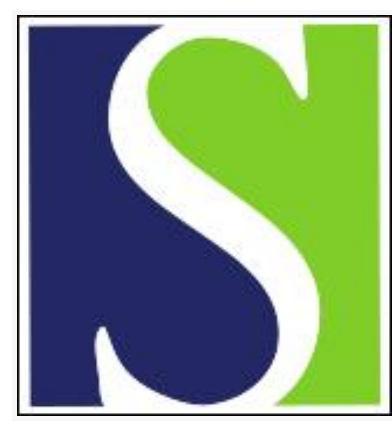

Scand J Work Environ Health 1993;19(6):394-398

https://doi.org/10.5271/sjweh.1456

Issue date: 01 Dec 1993

Work content of Norwegian occupational physicians.

by Wannag A, Nord E

Affiliation: Department of Health and Society, National Institute of Public Health, Oslo, Norway.

This article in PubMed: www.ncbi.nlm.nih.gov/pubmed/8153591 


\title{
Work content of Norwegian occupational physicians
}

\author{
by Axel Wannag, MD, Erik Nord, PhD ${ }^{1}$

\begin{abstract}
WANNAG A, NORD E. Work content of Norwegian occupational physicians. Scand J Work Environ Health 1993;19:394-8. There is little empirical knowledge of the work done in occupational health services. In a study of the work of 50 Norwegian occupational physicians, their work on 249 workdays was recorded and classified into nine different categories according to the work content. Most $(40 \%)$ of the work concerned work environment matters, $26 \%$ went to nonwork-related activities, $18 \%$ was for administration, $4 \%$ was for personal proficiency, and $12 \%$ went to various other activities. A total of $36 \%$ of the work concerned preventive activities, and $30 \%$ involved curative activities, of which two-thirds $(22 \%)$ was for nonwork-related illnesses. This latter figure seems large in comparison with the preventive aims of occupational health services given by the Norwegian labor inspectorate. The physicians spent little time on educating employees about work environment matters and on new projects to ensure good work environment standards. The amount of activity involving occupational rehabilitation was fair.
\end{abstract}

Key terms: classification, evaluation, health service research, occupational health services.

The World Health Organization has repeatedly advocated evaluation research on occupational health services (1-3), but no empirical studies of the work in such services is registered in Medline, Excerpta Medica, Sociological Abstracts, or Toxline data bases. In Norway, only two studies (with limited information on the work content and some information on activities in occupational health services) have been published previously $(4,5)$. This lack of empirical knowledge has hampered the reforms of Norwegian occupational health services and is one of the reasons discussions of the efficiency of Norwegian occupational health services have not been very constructive $(6,7)$.

In order to develop occupational health services according to changing concepts, resources and tasks, we need knowledge of the ongoing work done by such services. To obtain this information, we must be able to determine the content - the subject matter - of the different work tasks of occupational health services. Such data will make it possible to answer policy-relevant questions about occupational health services, particularly questions regarding priority setting and effectiveness.

This study was undertaken to obtain data on the content of occupational physicians' work by studying the distribution of their work time in different work tasks.

\footnotetext{
1 Department of Health and Society, National Institute of Public Health, Oslo, Norway.
}

Reprint requests to: Dr A Wannag, Department of Health and Society, National Institute of Public Health, Geitmyrsveien $75, \mathrm{~N}-0462$ Oslo, Norway

\section{Subjects and methods}

Fifty occupational physicians working half- to fulltime in two cities in Norway were randomly chosen to be interviewed. The interviews took place between September 1990 and February 1991. No major influenza epidemic or other events which could have substantially influenced the requests for services occurred during the registration period.

The physicians were registered for gender, age, workhours in occupational health services, if working alone or with other occupational physicians, their total workhours in occupational health services, total workhours of all personnel in the services, and the number of employees attended by the services. These last figures were used to calculate the worktime resources of the occupational health services, defined as the number of employees attended by one work year of personnel. The figures were calculated both for the physicians only and for all personnel. Last, the organizational type (of which there were nine) and the number of professions (an indication of knowledge resources) in the services were recorded.

Each physician was interviewed on the telephone at the end of five workdays. The same interviewer made all of the interviews. Altogether 249 days with 1858 workhours were covered. For each physician the interviews were spread over all the different weekdays worked. The days were picked arbitrarily and without any knowledge in advance of what the physician had been doing that day. Each interview lasted from 15 to $45 \mathrm{~min}$. The physicians recalled their different work tasks during the day, and the time spent on them, in chronological order. They were urged to use available records to support their mem- 
ory. Specifically, they were asked to state whether they saw a work task as work-related or not. All time within office hours, including lunch, and all additional work for the occupational health services outside office hours was recorded for each day. All of the information was recorded in detail by the interviewer, who later assigned the recorded work tasks and the time spent on them to nine different categories using the classification system constructed by Wannag (8). The system is easy to use and has good interrater and test-retest reliability (8). The categories defined in the instrument are as follows: (i) securing future work environments, (ii) surveying and securing the current work environment, (iii) individual work-related aid and surveillance, (iv) occupational rehabilitation of individuals, (v) influencing individuals' life-styles, (vi) individual nonwork-related aid, (vii) administration, and (viii) education of occupational health service personnel. We added a ninth category, other, which included time for travel between office and workplaces, lunch without discussions of medical or administrative subjects, contacts not related to work in occupational health services, and time for private affairs.

The concept of an illness or an event being workrelated is central to an evaluation of the activity of occupational health services. However, the definition used by the World Health Organization for work-related illness is ambiguous (9). It comprises both the fact that work (to various extents) can cause illness and the fact that work can influence (most often aggravate) many illnesses once they are established, whether factors in work or outside work are the causative agents. While it should be fully recognized that all illnesses and disabilities may be influenced by work, for a categorization of the work in occupational health services, it seems better to restrict the concept of work-related illness to those conditions in which a factor at work is the major cause. We used this, more restricted, view of work-related illness (which is common among Norwegian occupational physicians) in our study. However, due to the lack of an accepted objective standard, each physician had to use his or her own subjective standard when deciding whether an illness was work-related or not.

Events other than illness were considered workrelated if they (i) arose during the performance of work or (ii) came about because of specific demands from the job.

In the assessment of reliability, 210 work tasks classified in September 1990 were reclassified by the same interviewer three and six months later. The $95 \%$ confidence interval for the combined kappa was $0.91-0.95(10)$.

The physicians were able to account for more than $99 \%$ of their work time. The time not accounted for was added to the recorded work of the same days on a percentage basis.

The length of the workdays ranged from 2 to 12 $\mathrm{h}$, the average being $7.5 \mathrm{~h}$. To be able to treat work- days of different length in the same analysis, we calculated the time in the different categories for each workday as a percentage of the total work time of that day. From these percentages the distribution of the work time among the categories and among the work tasks could be calculated for a constructed "average workday."

We sampled the recorded workdays by first randomly selecting 50 occupational physicians and then five workdays for each physician. This two-step procedure increased the possibility that the sample was not representative of the universe of workdays of occupational physicians. The standard error of the results was therefore adjusted by a factor of the square root of 1.5 - the correction factor commonly used by the Central Bureau of Statistics of Norway for two-step sampling (11).

Simple cross-tabulations of the variables recorded for the physicians and for the occupational health services were used when we searched for indications that these variables could explain the differences in the distribution of the occupational physicians' work.

\section{Results}

Table 1 shows the distribution of the work time in the work categories for an average workday, while table 2 shows the composition of selected categories. As can be seen from the standard deviations (table 1), the day-to-day variation in the work done by occupational physicians is large. The largest categories were individual nonwork-related aid $(22 \%)$ and administration (18\%).

Forty percent of the physicians' time was spent on work-related activities in the first four categories,

Table 1. Distribution of occupational physicians' work between different work categories - work as a percentage of the average workday, calculated from 249 workdays.

\begin{tabular}{|c|c|c|c|}
\hline Work category & Mean & $\begin{array}{l}\text { Standard } \\
\text { deviation }\end{array}$ & $\begin{array}{l}\text { Standard } \\
\text { error } \\
\text { of mean }\end{array}$ \\
\hline $\begin{array}{l}\text { 1. Securing future work } \\
\text { environments }\end{array}$ & 3 & 9.5 & 0.7 \\
\hline $\begin{array}{l}\text { 2. Surveying and securing } \\
\text { current work environment }\end{array}$ & 12 & 15.8 & 1.2 \\
\hline $\begin{array}{l}\text { 3. Individual work-related aid } \\
\text { and surveillance }\end{array}$ & 18 & 14.2 & 1.1 \\
\hline $\begin{array}{l}\text { 4. Occupational rehabili- } \\
\text { tation of individuals }\end{array}$ & 7 & 9.5 & 0.7 \\
\hline $\begin{array}{l}\text { 5. Influencing individuals' } \\
\text { life-style }\end{array}$ & 4 & 6.3 & 0.5 \\
\hline $\begin{array}{l}\text { 6. Individual nonwork-related } \\
\text { aid }\end{array}$ & 22 & 17.4 & 1.3 \\
\hline 7. Administration & 18 & 20.5 & 1.6 \\
\hline $\begin{array}{l}\text { 8. Education of occupational } \\
\text { health personnel }\end{array}$ & 4 & 15.8 & 1.2 \\
\hline 9. Other & 12 & 9.5 & 0.7 \\
\hline
\end{tabular}

a The calculated standard error has been adjusted by the square root of 1.5 . 
Table 2. Amount of work in different tasks of work categories $2,3,4$ and 6 - work as a percentage of the average workday, calculated from 249 workdays.

\begin{tabular}{|c|c|c|}
\hline Work category & Mean & $\begin{array}{l}\text { Standard } \\
\text { error of } \\
\text { mean }^{2}\end{array}$ \\
\hline \multicolumn{3}{|l|}{$\begin{array}{l}\text { Category } 2 \text { - surveying and securing } \\
\text { current work environment }\end{array}$} \\
\hline $\begin{array}{l}\text { Surveying, securing and information } \\
\text { on the work environment }\end{array}$ & 7 & 0.9 \\
\hline $\begin{array}{l}\text { In medical check-ups } \\
\text { In other work tasks }\end{array}$ & $\begin{array}{l}0.5 \\
6.5^{\circ}\end{array}$ & 0.1 \\
\hline $\begin{array}{l}\text { Assistance solving psychosocial } \\
\text { conflicts }\end{array}$ & 2 & 0.6 \\
\hline $\begin{array}{l}\text { Education of employees about work } \\
\text { environment matters }\end{array}$ & 1 & 0.5 \\
\hline Various other tasks & 2 & 0.5 \\
\hline $\begin{array}{l}\text { Category } 3-\text { individual work-related } \\
\text { aid and surveillance }\end{array}$ & 18 & 1.1 \\
\hline \multicolumn{3}{|l|}{$\begin{array}{l}\text { Preventive - documentation of past } \\
\text { and current work environment exposures } \\
\text { and surveys for adverse heaith effects }\end{array}$} \\
\hline $\begin{array}{l}\text { In medical check-ups } \\
\text { In other work tasks }\end{array}$ & $\begin{array}{l}7 \\
3^{b}\end{array}$ & 0.8 \\
\hline \multicolumn{3}{|l|}{$\begin{array}{l}\text { Curative - aid for work-related } \\
\text { accidents, diseases and problems }\end{array}$} \\
\hline $\begin{array}{l}\text { In face-to-face consultations } \\
\text { Additional paperwork }\end{array}$ & $\begin{array}{l}5 \\
3^{\mathrm{b}}\end{array}$ & 0.5 \\
\hline $\begin{array}{l}\text { Category } 4-\text { occupational rehabilitation } \\
\text { of individuals }\end{array}$ & 7 & 0.7 \\
\hline Rehabilitation of addicts & 2 & 0.3 \\
\hline $\begin{array}{l}\text { Rehabilitation for physical and } \\
\text { psychological disabilities }\end{array}$ & 3 & 0.5 \\
\hline Work with sick leave & 1 & 0.4 \\
\hline Various tasks & 1 & 0.2 \\
\hline Category 6 - individual nonwork-related aid & 22 & 1.3 \\
\hline Face-to-face consultations & 12 & 1.1 \\
\hline $\begin{array}{l}\text { In office consultations } \\
\text { In medical check-ups }\end{array}$ & $\begin{array}{l}8.5^{\circ} \\
3.5\end{array}$ & 0.6 \\
\hline Additional paperwork & $10^{\mathrm{b}}$ & \\
\hline
\end{tabular}

a The calculated standard error has been adjusted by the square root of 1.5 .

bstimated value

while $26 \%$ of their time covered nonwork-related problems in the fifth and sixth categories. The remaining $34 \%$ of their time was spent on administration, maintaining their proficiency, driving between workplaces, and activities not related to work in occupational health services.

Preventive work is found in categories $1,2,4$, and 5 , altogether $26 \%$ of the work time (table 1 ), and in part also in category 3 . Close inspection of the work tasks in category 3 (eg, documenting the employee's exposures from work and health surveys of employees exposed to workplace hazards) suggests that the preventive part comprised around $10 \%$, and the curative part around $8 \%$, of the physicians' work time (table 2). Thus altogether $36 \%$ of the physicians' work time went to preventive activities. Curative work took $8 \%$ of their work time for work-related problems in category 3 , and $22 \%$ for nonwork-related problems in category 6 . Altogether $30 \%$ of the physicians' work time was spent on curative activities.

Table 3 shows that face-to-face consultations with employees occurred on at least four out of five work-
Table 3. Distribution of occupational physicians' workdays with different amounts of face-to-face consultations or medical check-ups.

\begin{tabular}{lcc}
\hline $\begin{array}{l}\text { Number of face-to- } \\
\text { face consultations } \\
\text { or medical check-ups }\end{array}$ & $\begin{array}{c}\text { Workdays with } \\
\text { face-to-face } \\
\text { consultations } \\
\text { (N) }\end{array}$ & $\begin{array}{c}\text { Workdays with } \\
\text { medical } \\
\text { check-ups } \\
(\mathrm{N})\end{array}$ \\
\hline 0 & 47 & 140 \\
$1-3$ & 92 & 50 \\
$4-6$ & 57 & 32 \\
$7-9$ & 30 & 10 \\
$10-14$ & 18 & 15 \\
$15-19$ & 5 & 2 \\
\hline Total & 249 & 249 \\
\hline
\end{tabular}

days. A total of $12 \%$ of the average workday was spent on face-to-face consultations for nonwork-related conditions, with an additional $10 \%$ for paperwork and telephone conversations (table 2). These consultations lasted an average of about 18 min each.

The average consultation for work-related problems lasted about $25 \mathrm{~min}$, and the occupational physicians spent $8 \%$ of their average workday on these matters. Five percent was in face-to-face consultations, and 3\% was with additional paperwork and telephone conversations (table 2).

Medical check-ups took place on less than half of the workdays (table 3 ), but a total of $14 \%$ of the average workday was spent on this activity $11 \%$ from categories 2,3 , and 6 in table 2 and $3 \%$ from category 5 "influencing individuals' life-styles" in table 1). Medical check-ups lasted an average of about 33 min and mainly dealt with $(7 \%)$ work in category 3 "work-related aid and surveillance" — documenting the employees' exposures from the work environment and checking for possible work-related health problems (table 2). The occupational physicians also paid due attention to influencing life-style risks (3\%).

Even if only a few of the physicians announced the possibility for employees to consult during medical check-ups, employees invariably used the opportunity to ask for curative help. The problems raised were nearly all nonwork-related matters, and the employees would probably not have raised them with the occupational physician at all if they had not been called for a medical check-up. Altogether these consultations took a quarter of the work time $(3.5 \%)$ of the medical check-ups (table 2).

Few physicians seemed to use the medical checkups to collect systematic information on the work environment in category $2(0.5 \%)$ (table 2 ).

Cross-tabulations did not reveal any significant correlation between the characteristics of the occupational physicians or the occupational health services on one hand and the distribution of the work time on the other. However, the number of physicians in the different subgroups was limited, especially when one looks at the nine different organizational types of occupational health services. 


\section{Discussion}

Our sample had obvious limitations. The number of occupational physicians was small, the physicians were all in urban areas, and we did not include physicians working less than half-time in occupational medicine. On the other hand, in terms of the number of workdays examined, the sample was substantial. This conclusion is reflected in the small standard errors. Moreover, most employees covered by occupational health services receive services from professional occupational physicians working more than half-time in occupational medicine.

There is a danger of recall bias and strategic bias in a study of this kind. However, interviews at the end of the workday bring the registration close to prospective (tomorrow) registration, the ideal for registering activity. Our impression was that the physicians were able to reconstruct their workdays and did so spontaneously, without applying censorship.

Altogether, we feel that the data reflect work content and priority setting in Norwegian occupational health services well. Unfortunately, as previous studies $(4,5)$ have used different categorizations and registrations, it is difficult to compare the results with older data.

The aims of Norwegian occupational health services are given by the labor inspectorate (12) and are in accordance with the convention proposed by the International Labour Office in 1985 (13). Occupational health services are supposed to be preventive and to assist management and employees in creating and securing safe work conditions by (i) improving the work environment, (ii) surveying the health of employees in accordance with their workplace exposures, and (iii) rehabilitation. The tasks within these general aims have, to a fair extent, also been specified in publications from the Norwegian labor inspectorate (12).

Other countries have broader aims for their occupational health services, also giving them tasks within the realm of general public health and curative medical treatment $(9,14,15)$. Thus the results of this study are mostly of interest to countries who apply their occupational health services more restrictedly to prevent ill health from exposures at work.

The Norwegian labor inspectorate has especially stressed the importance of securing the work environment when new activities and organizations are established. However, we found that only $3 \%$ of occupational physicians' time was devoted to such work. One reason may be that, in the larger occupational health services, persons other than occupational physicians handle these projects. However, because of the economic recession taking place during the study, most firms might not have projects creating new work environments at all. But it is also possible that the firms were not interested in having their occupational physicians engaged in these projects.
Twenty-two percent of the occupational physicians' work time went to treatment and aid for nonwork-related health problems. This value seems high when it is considered that occupational health services should be doing preventive work. The labor inspectorate states that consultation and cure should, under no circumstances, take priority over preventive tasks in occupational health services. Substantial pressure on occupational health services for consultations and treatment has been documented from employees and management $(4,16)$, and this pressure, in part, may explain the amount of curative activity. In this field comparative studies between The Netherlands and Norway could be very interesting. Plomp (17) found that Dutch employees who rated the activities they wanted their occupational health services to provide gave medical treatment a relatively low score, presumably creating little pressure on the occupational health services to deliver treatment. In addition, occupational health services in The Netherlands have strictly preventive aims. Even so, Dick Draaisma has so far found that about $10 \%$ of the work of Dutch occupational physicians goes to general consultations (Dick Draaisma, personal communication).

In addition, Svarva (5) has shown that personnel in occupational health services, in cooperation with employees and management, can establish occupational health services with very little curative activity for nonwork-related conditions.

Around 1980 Natvig (4), and later Svarva (5), found that about $5 \%$ of the work time in occupational health services is spent on rehabilitation. These activities seem to be increasing, as we observed that the occupational physicians alone spent $7 \%$ of their work time on occupational rehabilitation.

The labor inspectorate has repeatedly highlighted the importance of educating employees to enable them to identify risks in their work environment and to take action against such risks. According to table 2 , only $1 \%$ of the occupational physicians' time went to this education. However, some information with educational aspects is contained in the reports and discussions following surveys of the work environment, but altogether education of employees seemed to receive little attention.

The "other" category occupied $12 \%$ of the work time. It contained various work tasks considered not to be directly involved in the work of occupational health services. However, some of these tasks decisively support the work of occupational health services, and others are unavoidable. It is difficult to judge if $12 \%$ of an occupational physician's work time should be considered too much for these activities.

Eighteen percent of the average workday went to administrative tasks. Swedish occupational physicians, generally working in larger occupational health services with the support of administrative personnel, spent around $10 \%$ of their time on administra- 
tion (18). It seems as if occupational health services in Norway have a potential to increase the efficiency of its administration. But it also seems fair to suggest that the amount of administrative work for occupational physicians has been underestimated by the government and employers.

None of the variables concerning occupational physicians or the occupational health services where they worked seemed to explain the observed differences in the work of the occupational physicians. We had thought that the structure of the situation in which the physicians worked, expressed as the calculated worktime resources and the type of occupational health services, would have explained some of the differences. That this was not the case is interesting, but we shall need more observations in a larger study before drawing conclusions about this possibility.

\section{Concluding remarks}

This study shows that the work of Norwegian occupational physicians is oriented towards work environment matters ( $40 \%)$, with emphasis on prevention. However, a substantial amount (30\%) of their work still goes to curative activities, and two-thirds of this time is devoted to nonwork-related conditions.

Only with caution could our data be compared with data from other studies. The need to establish common categories and definitions for the registration of work in occupational health services in future studies should therefore be stressed. To gain further insight into the process of occupational health services and the factors which influence their priorities, we should be able to study the individual work of all personnel in occupational health services. Occupational physicians are only a part of the occupational health service team. Such studies of the process in occupational health services can probably be done with instruments similar to the International Classification of Primary Care (19).

\section{References}

1. World Health Organization (WHO). Evaluation of occupational health and industrial hygiene services. Copenhagen: Regional Office for Europe, WHO, 1982. (EURO reports and studies; no 56.)

2. World Health Organization (WHO). Health promotion for working populations. Geneva: WHO, 1988. (WHO technical report series; no 765.)
3. Järvisalo E, Kalimo E, Lamberg M, Rantanen J, ed. Occupational health as a component of primary health care. Helsinki: National Board of Health in Finland, 1986. (Publications of the National Board of Health in Finland; no 94.)

4. Natvig H. Bedriftshelsetjenesten i Norge. Nå - og i fremtiden [The occupational health service in Norway - now and in the future]. Oslo: Tiden, 1979.

5. Svarva A. Idealer og realiteter i bedriftshelsetjenesten [Ideals and realities in the occupational health service]. Tromdheim: Institutt for industriell miljøforskning, 1986. (SINTEF rapport; nr STF 82 A86009.)

6. Steen A. Offentlig styring i privat sektor. Styringsambisjoner og konflikter i bedriftshelsetjenesten i Norge [Public governing in the private sector: the will to govern and the conflicts in the occupational health service in Norway]. Oslo: Institutt for statsvitenskap, Universitetet i Oslo, 1992. (Forskningsrapport 01/92.)

7. Natvig H, sen Thiis-Evensen E. Arbeidsmiljø og helse. Yrkeshygienens og bedriftshelsetjenestens frembrudd og utvikling i Norge [The work environment and health: the start and development of occupational heath service in Norway]. Norsk bedriftshelsetjeneste 1983; $4: 1-333$.

8. Wannag A. Classification system for work in occupational health services. Scand J Work Environ Health 1993;19:390-3.

9. World Health Organization (WHO). Identification and control of work-related diseases. Geneva: WHO, 1985. (Technical report series; no 714.)

10. Fleiss JL. Statistical methods for rates and proportions. New York, NY: Wiley-Interscience, 1981.

11. Central Bureau of Statistics of Norway. Health survey 1985. Oslo: Central Bureau of Statistics of Norway, 1987.

12. Bedriftshelsetjenesten [The occupational health service]. Oslo: Arbeidstilsynet, 1990. (Bestillingsnr 501.)

13. International Labour Office (ILO). International labor conference 71 st session: occupational health services. Geneva: ILO, 1985. (Report IV(1).)

14. International Labour Office (ILO). International labor conference 70th session: occupational health services. Geneva: ILO, 1984. (Report V (1).)

15. International Labour Office (ILO). International labor conference 70th session: occupational health services. Geneva: International Labor Office, 1984. (Report $\mathrm{V}(2)$.)

16. Vatshelle $\AA$. Forventninger til bedriftshelsetjenestekontroll [Expectations of the medical check-up]. Nor bedriftshelsetj 1988;(5):295-305.

17. Plomp HN. Worker's attitude toward the occupational physician. J Occup Med 1992;34:893-901.

18. Svenska företagsläkarföreningen. FAFLA: Fördelning av företagsläkarens arbetstid [The distribution of the working hours of occupational physicians]. Företagsläkaren 1989;3:4-10.

19. Lamberts H, Wood M, ed. ICPC, International classification of primary care. Oxford: Oxford University Press, 1983.

Received for publication: 11 January 1993 